\title{
Introduction to the Special Section: Discourses of Economic Behaviour in Times of Instability
}

\author{
ZSUZSA GILLE and MARTIN HÁJEK
}

The three articles collected in this thematic section respond to the contemporary interest in understanding how the economy is both presented and represented in society through discourse and what consequences this discourse has for institutional policies, individual subjectivities as well as everyday life in general. All three papers base their arguments on datasets from Czech society: Hájek and Samec focus on the state socialist period (1948-1989); Kala, Galčanová and Pelikán on post-socialism (after 1989); and, finally, Čada and Ptáčková investigate the contemporary period, while their findings reveal the enduring legacy of the socialist past. The continuities and discontinuities are likely to resonate with experiences elsewhere in Central and Eastern Europe (CEE).

Because the articles engage with economic discourses in the state-socialist and post-socialist Czech Republic, and because post-structuralism attributes particular political agency to discourse, it is useful to recall how most social scientists understood the relationship between economy and politics in state socialism and capitalism. The very wording of what a socialist society was-a command economy-already suggests that the economy didn't enjoy the kind of freedom from state intervention it allegedly regularly does in a market economy. The party-state, which after all was also the owner of the means of production, decided what to produce and how much, and handed those quotas down to the enterprises, which were legally obliged to fulfil them. It is through this centralised bureaucratic system that inputs and outputs were distributed as well, and, as observers knew even back then, not very successfully. Shortages, long queues, and low-quality goods were common occurrences. It is in part the autonomous mechanism, by which centrally planned economies couldn't help but generate chronic shortage and waste [Kornai 1980; Gille 2007], that gave nuance to the alleged binary opposition of socialism and capitalism. From the western side, the binary had been crumbling ever since Karl Polanyi demonstrated how free markets are not born but made, and how the seeming autonomy of the economic realm is an achievement of specific political and economic actors rather than a natural state of society. Since then, of course, the many, in most cases Marxisant, studies about the tendency of capitalist markets towards monopoly and the state's active role in helping to absorb surplus only further blurred the boundary between the economic and the political. If the socialist economy had its own laws of motion [Ticktin 1992] and could not be made to bend to every political intention, and if the western markets were not immune to government projects and assistance, 
then how do we capture the difference in the nature of economic discourse in each type of society?

One way to proceed is to distinguish different scales on which economic discourses operate. Clearly, even without a state that dictates to producers and consumers, there are many more subtle ways to shape their behaviour. Here we'll focus on three: social norms, trivialised economic expertise, and advertising. Social norms shape how much individuals spend on certain things, how many pairs of shoes is too many, how much to save, what is a good reason to take out a loan, or how much pocket money parents should give their children. These norms, of course, vary strongly by class, religion, type of settlement (rural, small urban, metropolitan), race, and ethnicity, though in a small and relatively homogenous country such as the Czech Republic they tend to be more widely shared than in the United States, for example. Such norms operate on a macro scale, at the level of local communities, and at the level of family.

Economic expertise informs many of the fiscal policies that set tax rates, currency exchange rates, interest rates, and employment and development policies, which collectively provide the incentive structure for economic decision-making by individuals and families. Trivialised economic knowledge is a popularised and simplified version of academic expertise and it tends to exert its influence on the macro level. Tenets, for example, that assert economic growth as a good thing or that the inflation rate should be below a certain percentage-as we've seen in Germany recently - can influence and legitimate the policies of national governments. The suggestion by heads of state in response to the 2008 crisis that consumers should go out shopping is a recent example. Social norms in modern societies can and are influenced by economics. A more abstract economic dogma that percolates into social norms and everyday practices, for example, is that the more choices consumers have, the better-both for the consumer and the economy as a whole, due to competition which promotes efficiency and drives innovation.

Finally, advertising, especially in its contemporary form, that tends to sell not so much commodities as identities and lifestyles allegedly facilitated by commodities, exerts strong influence on economic discourse, primarily at the level of the family and individual. The effect of advertising was expected to be especially strong in post-socialist societies, because advertising had previously existed only to a limited extent, and often had been subordinated to the party's economic goals [Ghodsee 2011]. Cinematic commercials with vibrant hues probably had a greater sensory impact on a population that lacked the savviness of the western consumer. This impact, however, is far from evident. To be sure, there is some truth to the common-sense perception of eastern Europeans as starved consumers who were eager to acquire commodities previously in shortage or denied outright to them. However, moderating the ability of ads to compel post-socialist subjects to shop were (a) their low purchasing power; (b) their socialisation under communism that chastised pleasure-seeking consumption; and (c) their resentment over the disappearance of traditional, domestic brands that had been well liked. 
The authors in this issue find the Czech economic subjects at the intersection of these contradictory pressures. After almost three decades of post-socialism, during which a whole new generation has come of age, it is particularly important to evaluate how economic values and practices have been transformed. What do parents teach their children about the balance between being frugal and being cheap? What values and practices allow young families to exempt their members from the pressures to make and spend an increasing amount of money, while still wanting to lead a comfortable life? What are the continuities and discontinuities in economic discourse? How do Czechs think of themselves as economic actors and ethical subjects at the same time? What is a taboo and what is an explicit proscription? What is taken for granted in these discourses and what do they tell us about the nature of eastern European capitalism?

The recent past of CEE, i.e. a sequence of late state socialism, transformation, and capitalist consolidation, created two types of economic taken-for-grantedness that can contradict or support each other. The first taken-for-grantedness has grown from a deeply sedimented experience of living in a state-socialist society characterised by prosumer and DIY activities, by the maintenance of networks of friends and acquaintances in order to ensure provision of services from bureaucratic institutions, and by repetitive propaganda rituals which were transparently hypocritical. Different from this taken-for-grantedness but nevertheless influenced by it is the new experience of the building of a capitalist society. Capitalism gained its legitimacy from the coveted values of freedom, prosperity, and meritocracy. To be sure, the transformation of everyday life was nothing short of extraordinary, but generally it was accepted as a necessary and truth-revealing step in order to get rid of old habits, 'inefficient', and 'paternalist' state-socialist mentalities that put too much faith in solidarity and mutual help. A new economic thinking was supposed to take hold, centred on the metaphor of the 'invisible hand' of the free market. Two things in particular kept economic liberalism from becoming fully internalised. One was the importance of political and social capital for acquiring economic capital ('having friends in the right places'), and more particularly, corruption. The other was the enduring usefulness of many of the economic survival strategies developed under state socialism. These are not simply legacies but are reinforced and reproduced in somewhat modified form even three decades after the collapse of the socialist camp. In sum, as the capitalist economy has consolidated in the new century, the second taken-forgrantedness did establish itself but it never fully replaced the old one; rather they exist, sometimes in more tension, sometimes in less, side by side.

Bourdieu would say that there are actually two doxa and two sorts of habitus in post-transformation societies. Each has the capacity to subvert the other-or at least they prevent each other from developing the unreflexivity doxa usually possess. Discourse therefore becomes a tool with which institutions and individuals manage and temporarily reconcile these two types of taken-for-grantedness. People in CEE speak about their economies as different from the Western 
'standard', and, by the same token, even if they would like to have the same level of affluence as their western counterparts, they have explicit reasons for doing things in their own way. It is their specific past that justifies being different from the global 'mainstream'. For example, Lukáš Kala, Lucie Galčanová and Vojtěch Pelikán make just that point about the voluntary simplifiers (New Colourful) in the Czech Republic. In explaining - and thus legitimizing - their frugal way of life they use the discourse of simplifiers in affluent societies, even though they themselves have not experienced the kind of affluence that voluntary simplicity reacted against in the West. Because of their reflexive awareness of the socialist consumer past and the contemporary capitalist logic they do not need to directly experience affluence in order to refuse the Western consumerist lifestyle. The double taken-for-grantedness enables them to discursively legitimate their ideals of a simple life without feeling like they need to express this choice in ideological terms. This is one reason why neoliberalism and indeed even capitalism remain unarticulated both by research subjects and by the authors in this thematic section.

In his ethnographic study of Romanian villagers, Umbres [2014: 127] found that in their livelihood strategies villagers do not rely either on government agencies or on society, as one would expect from post-socialist actors; rather, they appear like 'well-behaved neo-liberal subject[s]'. Martin Hájek and Tomáš Samec arrive at a similar conclusion after tracing the genealogy of the discourse on thrift in Czech socialist society. In their paper, they describe how the meaning of thrift in socialist economic discourse changed over time from productive to restrictive semantics, and both were eventually publicly sidelined by the concept of income increase. Nevertheless, people have learned that thrift as the rational management of resources could make them partially independent from ineffective state institutions, but without confronting the state. As Hájek and Samec show, socialist household manuals instructed households to become rational and planned economic units, avoiding unnecessary spending and thus contributing to the national economy. The unintended consequence of the combination of socialist consumers' disciplinary discourse and a persistent economy of shortage was the creation of cautious but nevertheless entrepreneurial-looking post-socialist consumer subjectivities, as preached by neoliberal ideology.

The failure to create a socialist consumer (not to mention the socialist worker) that would be both self-supporting and loyal to the socialist state was in part due to the strength of family economic discourse, in which the family, not the state, defined the horizon of relevance. Family conversations and proscriptions about proper ways to earn and spend money, cautionary tales about indebtedness, and norms about who can rely on what family member in meeting what economic need are key instruments for translating and domesticating publicly circulating discourses, such as the ones we alluded to above. In the post-socialist context, family discourses matter even more, because with the withdrawal of the 'nanny state', families were compelled to assume more responsibility for 
their well-being. Although Karel Čada and Kateřina Ptáčková did not originally set out to explain post-socialist consumer subjectivities, their findings about the moral codes of family economy do just that. Suggesting that '[b]eing prepared can be identified as the core of the discourse of the moral economy of the family', they make it clear that people's economic subjectivities are not a simple product of dominant economic ideology. Čada and Ptáčková are particularly interested in how the discourse of financial institutions is domesticated, how its promissory, calculative, and profit-oriented character is neutralised and adapted to be compatible with the familial discourse. They describe three mechanisms of the discursive domestication of financial products: narrativisation, appropriation, and affectivation. These provide powerful tools for families to resist the dominant public discourse of an increasingly financialised economy, which encourages the liquidation of fixed assets (such as borrowing against one's home or land) and the use of consumer credit.

The studies in this thematic section focus mostly on what in the western context is called the middle class. While they can be faulted for the exclusion of marginalised groups or the precariat from their samples, collectively they contribute to an understanding of the mechanisms by which economic subjects are produced and by which they exert agency. We thus see this collection as a modest contribution to a new and exciting body of research that studies the globally emergent middle class not as a universal and inevitable trend but as resulting from a momentum that unfolds unevenly through frictions and contradictions arising from local histories.

\section{References}

Čada, K. and K. Ptáčková. 2017. 'Domestication of Financial Objects: Narrativization, Appropriation and Affectivation.' Czech Sociological Review/Sociologický časopis 53 (6): 857-879.

Ghodsee, K. 2011. Lost in Transition: Ethnographies of Everyday Life after Communism. Durham, NC: Duke University Press.

Gille, Z. 2007. From the Cult of Waste to the Trash Heap of History: The Politics of Waste in Socialist and Postsocialist Hungary. Bloomington, IN: Indiana University Press.

Hájek, M. and T. Samec. 2017. 'Discourses of Thrift and Consumer Reasonability in Czech State-Socialist Society.' Czech Sociological Review/Sociologický časopis 53 (6): 805-831.

Kala, L., L. Galčanová and V. Pelikán. 2017. 'Narratives and Practices of Voluntary Simplicity in the Czech Post-socialist Context.' Czech Sociological Review/Sociologický časopis 53 (6): 833-855.

Kornai, J. 1980. Economics of Shortage. Amsterdam: North-Holland Pub. Co.

Ticktin, H. 1992. Origins of the Crisis in the USSR: Essays on the Political Economy of a Disintegrating System. Armonk, NY: M. E. Sharpe.

Umbres, R. G. 2014. 'Building on Trust: Open-ended Contracts and the Duality of Selfinterest in Romanian House Construction. Pp. 127-144 in Neoliberalism, Personhood, and Postsocialism: Enterprising Selves in Changing Economies, edited by N. Makowicky. Farnham, UK: Ashgate Publishing. 